inhibition was maximal between $10^{-4}$ to $10^{-5} \mathrm{M}$ concentrations, its rate differing in the single compounds. The coumarin proved to be ineffective in these experiments, whereas the vanillin promoted considerably the activity of the enzyme.

On the basis of the data the growth-inhibiting activity of the above-mentioned compounds seem not to be correlated with their effect exerted on the IAA-oxidase. Thus, the phenolic compounds likely exerted their growth-inhibiting effect not in this way but by some other mechanism.

Detailed results will be published elsewhere.

Institute for Plant Physiology, University of Szeged, Hungary

Magdalena Varga und Elisabeth Köves

Eingegangen am 25. April 1962

1) Varga, M.: Acta Biol. Szeged. 3, 213 (1957). - 2) Köves, E.: Acta Biol. Szeged. 3, 179 (1957). - 3) Köves, E., and M. VARGA: Acta Biol. Szeged 4, 13 (1958). - कYTON 12, 93 (1959). — ) GoRDon, S.A., and R. P. Weber: Plant Physiol. 26, 192 (1951).

\section{Alarm Substance and Intra-Specific Predation in Cyprinids}

When V. FRISCH${ }^{1}$ ) detected that in some cyprinids the olfactory perception of an alarm substance ("Schreckstoff"), liberated from the skin of an injured fellow member, elicits a fright reaction, two functions were attributed to this alarm substance:

1. to warn against predators, and

2. to prevent intra-specific predation.

Subsequent papers have dealt predominantly with the distribution of alarm substance among fish, and with the primary or secondary sensory mechanisms involved in the release of the alarm reaction ${ }^{2-4}$ ). It is very difficult to provide direct experimental evidence pro or con the supposed functions of alarm substance in fish, and it would seem that these functions have been accepted more or less as self-evident. The observations described in the present paper caution against the universal acceptance of alarm substance as having an important function in preventing intra-specific predation.

The observations were made in an aquarium of about 2001 containing some 50 freshly collected creek chubs (Semotilus atromaculatus MITCHILL) ranging from 4 to $12 \mathrm{~cm}$ in length. This is one of the North American cyprinids in which the occurrence of alarm substance has recently been demonstrated ${ }^{5}$ ).

When filtered meat juice was introduced into the tank the fish would start searching for food eagerly. Thereby the larger fish swimming closer to the bottom were seen making hunting movements after the smaller ones swimming at higher levels. Three times a large minnow succeeded in catching a smaller one. In one case it took about 20 minutes before the relatively large prey was swallowed completely by the predator. The other minnows were not disturbed at all by these events. Food introduced into the tank after the drama was over, was accepted immediately. Subsequent introduction of skin juice prepared from a minnow of about $4 \mathrm{~cm}$ in length provoked the well-known panic-stricken behavior. Feeding stopped and was not resumed after one hour.

Obviously the large minnows succeeded in swallowing the smaller ones without liberating alarm substance. Floating scales, generally accompanying the swallowing of a cyprinid by predators like perch or pike, were not seen during the observations under consideration. In part this may be due to the fact that in cyprinids teeth are only found deep in the pharynx. When the prey has arrived there any alarm substance resulting from damage to the skin would have not much chance to reach the water outside, because in all probability the prey is there completely surrounded by the pharyngeal walls of the predator.

The hypothesis that the alarm substance protects the cyprinid fry against predation by the more or less adult fish ${ }^{10}$ ), ${ }^{2}$ ) was based upon the observation of BERWEIN ${ }^{6}$ ) that minnows (Phoxinus laevis AGassiz) 8 to $9 \mathrm{~cm}$ in length were frightened after predation upon minnows 1.3 to $1.6 \mathrm{~cm}$ long. The conclusiveness of this observation seems to be doubtful because according to BERWEIN in many cases the intra-specific predation did not entail an alarm reaction among the predators. She stated, however, that in case the small fish was not caught at once but injured the school was clearly frightened. Her additional statement "this was observed both in normal minnows and in minnows in which the bulbi olfactorii had been taken away" (BERwEIN, p. 403, translated by author) makes things still more difficult to evaluate since the oltactory perception of alarm substance is crucial in evoking the fright reaction 1 )

BERWEIN's initial supposition that this intra-specific predation might be a "degeneration" of the minnows as a result of prolonged living in aquaria was invalidated by her observation that freshly collected minnows $8.5 \mathrm{~cm}$ in length immediately attacked minnows $3.1 \mathrm{~cm}$ long, however without really catching these obviously too large preys.

SCHUTZ ${ }^{2}$ ) interpreted his findings that the alarm substance is present in very small minnows long before they are themselves reactive to the substance as indicating that the function of the substance is to fright away predating adults. Reversedly it can be argued, however, that the smaller the fry the greater the chance that it is swallowed without liberation of the alarm substance, as was obviously the case in several experiments of BERWEIN.

Indeed the very fact that freshly collected cyprinids have the tendency to prey upon smaller fellow members argues against a strong inhibition - for instance by alarm substance of this behaviour pattern in nature.

A more effective protection against intra-specific predation seems to be attributable to the tendency of cyprinids to avoid the incorporation in their school of smaller or larger individuals. BERWEIN concluded from measurements and age determinations that a school of Phoxinus consists of individuals of the same year class. Several authors have found that schools of fish are generally composed of individuals of the same size class (for references see for instance ${ }^{7}$ ), ${ }^{8}$ ).

Finally it should be realized that considerations about the function of alarm substances in preventing intra-specific predation are based upon the presupposition that in fish like the cyprinids intra-specific predation is a detrimental factor for a species. It is very difficult, however, to decide what contributes more to the flourishing of a given species: that other predators decimate the fry of the species under consideration, or that larger individuals of this species are profiting from their own fry as a source of accumulated food.

Department of Fisheries, School of Natural Resources, University of Michigan, Ann Arbor, Michigan (U.S.A.)

Eingegangen am 5. Mai 1962

\section{F. J. VERHEIJEN *}

*) Present Address: Laboratory of Comparative Physiology, University of Utrecht, Jan van Galenstraat 17 , Utrecht (Netherlands)

1) Frisch, K.v.: Naturwissenschaften a) 26, 601 (1938); b) 29 321 (1941); - c) Z, vergl. Physiol, 29, 46 (1942). — 2) Sckuxz, F. Z. vergl. Physiol. 38, 84 (1956). -3) VERHEIJEN, F. J.: a) Experientia [Basel] 12, $202(1956)$; - b) Pubbl. Staz. Zool. Napoli 31, 146 (1959). - 4) PFEIFFer, W.: a) Naturwissenschaften 47,23 (1960); b) Z. vergl, Physiol. 43, 578 (1960), —5) VERHEXJEN, F. J.: MS. 6) Berwein, M.: Z. vergl. Physiol. 28, 402 (1941). -- ?) KeEnleySIDE, M.H.A. : Behaviour 8, $184(1955) .{ }^{8}$ ) BREDER jr., C. M.: Bull. Amer. Mus. Nat. Hist. 117, art. 6, 397 (1959)

\section{Dual Capacity of Differentiation of the Middle Piece in Hydra}

Two types of determinants, namely hypostome-wise and basaldisc-wise, exist in the organisation pattern of hydra. Topographically, the middle piece occupies a position in between the two opposing systems. Experiments were conducted to understand the nature of the differentiating capacity of the middle piece. Middle pieces were removed from the entire system as an isolate. Also, its determination as a graft in the vicinity of another hypostome as well as in the basal disc of another hydra had been tested. The common hydra, Hydra vulgaris (Pallas), phase orientalis (Annandale), was used as the material. Total number of experiments performed was 75 .

Experimental Series I: Differentiation of Middle Piece as an Isolate. A fragment of middle piece, when isolated from an unbranched slender hydra and chopped into pieces, differentiated first to develop tentacles in each rudiment. If the pieces were of good size, they, in isolation, after the formation of tentacles, formed a hypostome and a basal disc The middle piece had both potentialities of differentiation. Sevies 11: Differentiation of Midale Piece as a Graft in Anterion Region. A fragment of middle piece, when grafted in the anterior region of hydra, developed in 24 hours, a basal disc. The basal disc later grew and became a conspicuous structure on the body of the host. The host often used this extra basal disc as its foot. In case the grafts were put very near the host hypostome, the material became converted into an extra tentacle of the host. 